\title{
Human Capital and Performance of South Asian Economies: A Panel ARDL approach to Co- integration
}

\section{Adnan Akhter ${ }^{1}$, Syed Kashif Saeed ${ }^{2}$}

${ }^{1}$ PhD Scholar, Management Science Department, CUST Islamabad

${ }^{2}$ Assistant Professor, Management Sciences, PIEAS, Islamabad

\section{A B S T R A C T}

In modern times of knowledge management, intellectual capital grasped considerable attention not only from academia and corporate sector but also from national policymakers. Major intellectual capital component of an economy is human capital which comprises talents, knowledge, skills etc. that nation has, which render economic value. Collective abilities i.e. education, health, training, talents, megastructures, physical assets etc. of a nation, aids in growth and development of an economy. The scope of the study is to explore the long term boning between performance and intellectual capital facet aka human capital (HC) in South Asian economies. Human capital index, which incorporates different facets of human capital is used to explore its link with the economic performance of the region. Panel ARDL approach evidenced long term bonding between variables of interest. Further analysis corroborates bi-directional causality amongst human capital and performance of the economy. Nations must spend considerable attention towards the development of human capital besides flourishing physical capital, so that economy can grow and embellish in sustainable terms.

JEL Classification: O10, O15, O34, O40, O53.

KEYWORDS: Intellectual capital, Human Capital, Index of Human Capital, Physical capital, South Asian economies

\section{INTRODUCTION}

Developed nations acknowledged the importance of education and human development for economic growth. Their agenda remains an easy access to quality and basic education for their populace. Knowledge gained through education or technical training helps to develop an economy and lead towards economic growth to manifest good performance across the globe. In modern times of knowledge management, knowledge is considered to be the key source of economic development and the only way for

\section{Address of Correspondence}

Adnan Akhter

uims.adnan@gmail.com

\section{Article info}

Received July 17, 2017

Accepted Dec 25, 2017

Published Dec 30, 2017 
comparative advantage. The basic purpose of this study is to explore the long term bonding between human capital and performance in South Asian economies.

The emphasis of intellectual capital studies remained on explaining the role of intangibles as a decisive differentiator between book value and market value of corporations that provide a corporate competitive advantage. Human capital (HC), the major contributor to national intellectual capital, strikes the performance of the economy and helps to develop it through skills, talents, and knowledge of people. HC consists of a set of resources including skills, training, health, education and other talents. The better performing economy can be gauged through its growth which is an increase in economics' ability to produce better goods and services as compared to past periods.

Two major myths at national arena erode the development process of different nations. First, countries with an abundance of natural resources in-house are considered to be the most developed economies, Secondly, development of physical capital without a focus on human capital leads a nation towards progress. But reality exposed in the industrialization era that mere physical development is a hollow investment with no sustainable return in an economy. A plethora of economic growth theories posits that $\mathrm{HC}$ significantly plays its important role in the development process through investment in education, health, and well-being of the humans of the nation.

\section{Theoretical Background}

HC theory can be traced back to labor economics. Theodore Schultz in 1960 introduced the concept of human values and capacities. According to him, $\mathrm{HC}$ is same as other capitals; investment could be in HC through education, training and enhanced benefits that lead to melioration in the level and quality of production. Accordingly, some humans are more productive than others because of more invested resources in training, knowledge enhancement, skills development on them, same as production unit that demands more resources to be efficient and productive enough (Mueller, 1982). Like any business investment, an investment in the human will accrue more sustainable returns. According to this theory, investment in humans is made in diverse ways, not for sake of 
present pleasure only but for sake of future monetary and non-monetary benefits (Schultz, 1963).

HC theory gave insight into the development of the theory of intellectual capital (IC). According to Stewart (1997), the concept of IC has derived from the theory of human capital by specifically associating knowledge with capital. By singling out knowledge from the theory of $\mathrm{HC}$, IC identifies individual's knowledge, skills as assets to the nation. According to Stewart (1997) and Edvinsson and Malone (1997), IC is gradually becoming a viable alternative to making competitive leverage in the competitive environment because it encompasses the foundational components to do business.

According to HC theory concept by Schultz 1960, like any business investment, an investment in the human will accrue more sustainable returns. This theory posits that every nation has different skill sets or knowledge, which can be improved through investment in people's education. Accordingly, investment in the human resource is not only profitable in present time but it provides future monetary and non-monetary benefits to an economy (Schultz, 1963).

According to United nation (UN) Millennium Development Goals (MDG), "nations must ensure universal primary education for economic progress till 2015". UNESCO continuously monitored the nation's enrolment ratio of education to gauge the future development of the economy and reported in 2015 that MDG's regarding education progress is at standstill in South Asian economies. Majority of under developing nations and especially South Asian region failed to achieve this MDG-2 goal (UN, MDG 2015). Later on comity of nations transformed this MDG into Sustainable Development Goals (SDG), according SDG-4 emphasized on education importance for a sustainable development of the economy. According to goal SDG-4 'quality education is right of every citizen and till 2030 education for all must be implemented for economic progress of nations' but developing nations hardly pay any heed to the importance of education (UN, SDG 2016). Due to sheer importance of education for economic growth, the share of education, that built human capital, in progressive economies need to be empirically evaluated. 
According to Banco Bilbao Vizcaya Argentaria research report (BBVA, 2015), Bangladesh, India, and Pakistan are the major South Asian economies. Bangladesh spends $1.97 \%$ of their GDP on education while India and Pakistan spent $2.49 \%$ and $3.9 \%$ respectively. On the other hand literacy rate in these economies differ a lot. Literacy rate in Pakistan is 56.76\%, in Bangladesh 59.72\% while in India 74.04\% (2013 UNESCO report). Pakistan spent more than Bangladesh on education sector but literacy rate is less as compared to Bangladesh.

Figures 1, 2 and 3 elaborates the human capital index score of south Asian countries i.e. Bangladesh, India, and Pakistan. It is very evident that with the passage of time investment in education, skills development and learning of nation increases. In current times of knowledge management and borderless economies, humans are considered to be a big asset for the development of the nation in terms of growth, prosperity etc.

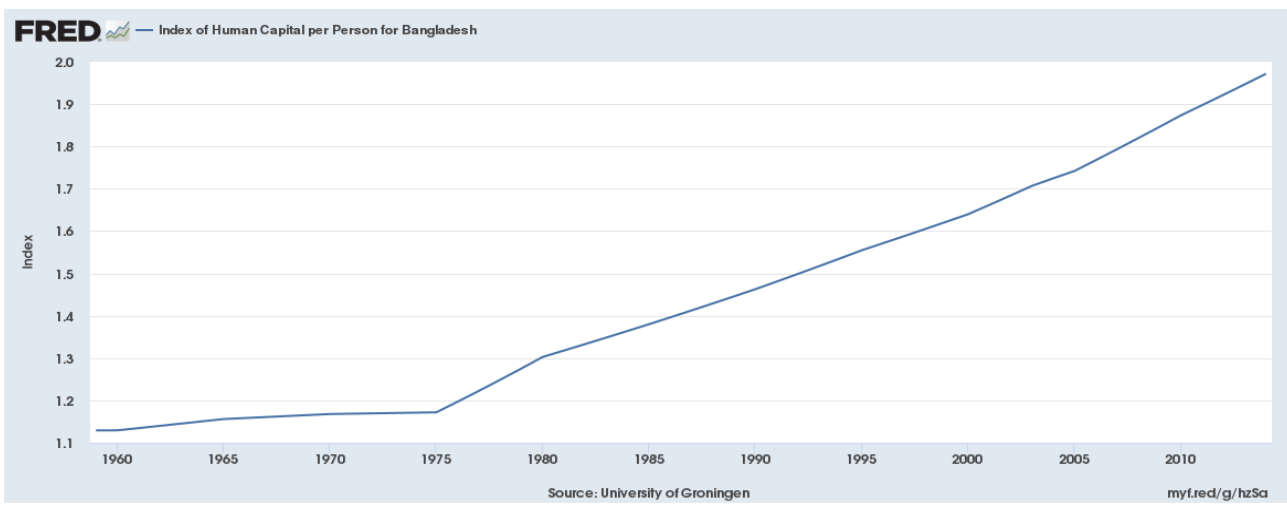

Fig 1. Index of Human capital (Bangladesh)

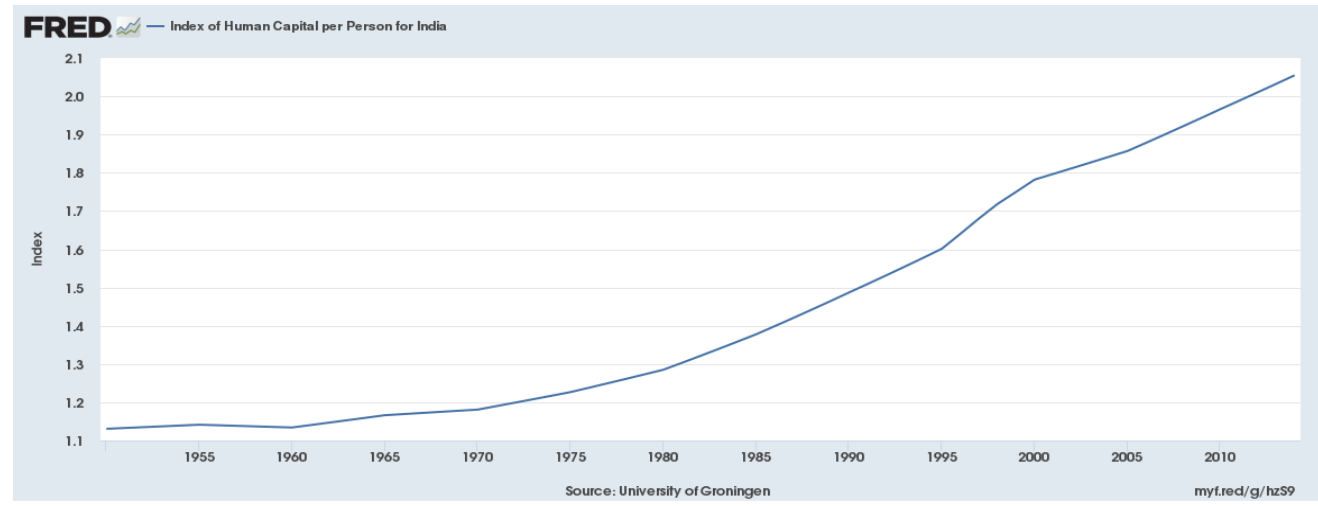

Fig 1. Index of Human capital (India) 


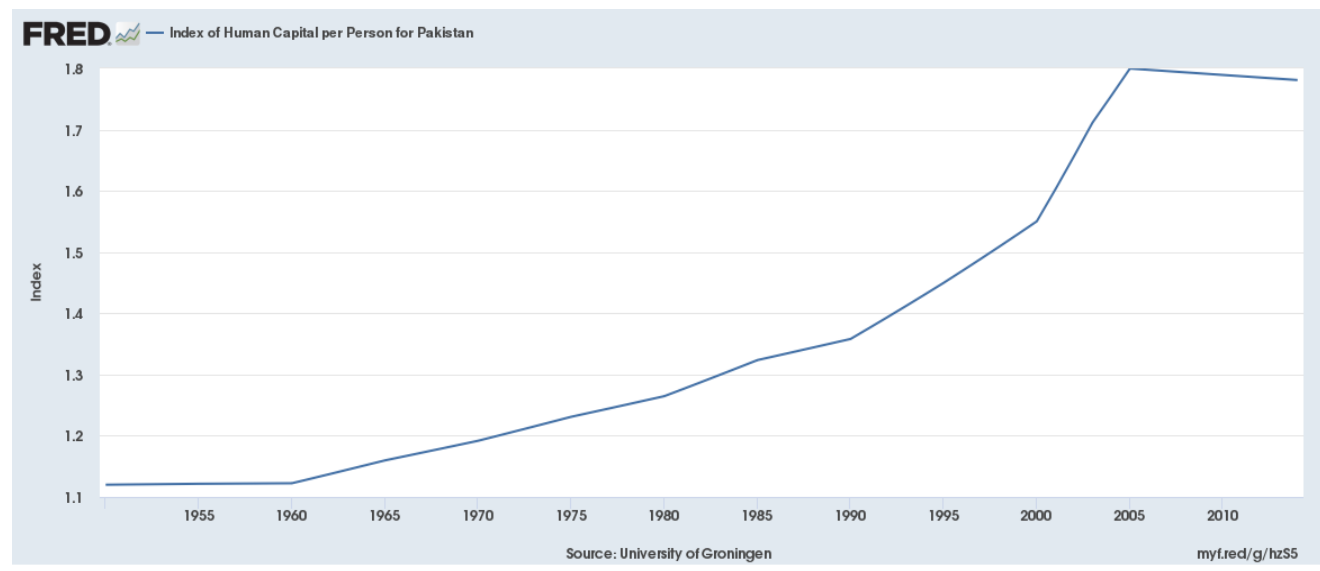

Fig 1. Index of Human capital (Pakistan)

It remained dilemma of developing nations that their main objective was to build physical capital earlier and pay little attention towards the intellectual or human capital economy. Education is the only factor that built the edifice of human capital which aids in economic prosperity and national development. With the surge in human capital investment specifically in last two decades as shown in figures above, it is necessary to explore the long term link of human as well as physical capital in economic growth. Investment in any asset always provides long term benefits, same goes for the human asset. Therefore its long term link with economic progress need to be explored. This study will explore empirically the long run link between human capital and economic performance across South Asian countries. As United Nations, advocates of human development emphasized on nations the grandness of education and its role in sustainable development.

The study is divided into five sections. Next section will explore the related literature which is followed by methodology, empirical results, and discussion along with conclusion and policy recommendations.

\section{LITERATURE REVIEW}

Future competitiveness will be based on knowledge economy besides other peripheral conditions for a nation to grow and prosperous (Edvinsson, 1997). The knowledge economy is based on the intellects which a nation possess, nurture and polish. Intellectual capital is the sum of all the intellects on which the edifice of knowledge 
economy stands. Solow (1956) articulated the most crucial aspect of such intellect of economy i.e. human capital. The role of human capital besides physical capital in economic progress cannot be ignored. A nation's growth is affected by factors including physical and human capital available in an economy (Barro and Martin, 1992). Any change in political, environmental, intellectual capital etc. directly affects the growth perspective of the economy. Barro (1991) corroborated that increase in human capital directly increases the growth rate of GDP if the level of physical capital held constant. In this way, the economy can achieve the desired level of growth, which manifests a positive link between HC and growth.

According to Barro (2001), literature is evident that either its developing or underdeveloped economies, human capital in long term posit significant and positive impact on economic growth. As Solow (1956) posits that long term economic growth can be determined in the neoclassical framework by a technological process which encompasses human capital in it. Jorgenson and Fraumeni (1989) explored that human and physical capital contributed in explaining United States of America growth rates almost $83 \%$ between the period of 1948-1986. While Barro (1991) empirically concluded that one percent increase in school enrollment is associated with an increase of almost three percent of the gross domestic product growth of the economy. There are interdependencies between economic growth and human capital economy according to endogenous growth theories. Concomitants to $\mathrm{HC}$, aids in developing and opting for matured technologies lead to growth enhancement of economy. Different studies revealed a chain of economic growth through human capital investment; the development of GDP carries investments in HC for nonstop economic ontogenesis. Thus, human capital increases the development value of GDP per capita which in return enhances $\mathrm{HC}$ and postulates bi-directional causality.

$\mathrm{HC}$ of an economy is the expenditure on education sector of all levels especially focused on the primary level. The literature on $\mathrm{HC}$ and economic performance associated education returns with economic growth in four ways. First, Education leads to labor efficiency which develops scientific and technological improvement. Second, Education develops the potential skills of the populace. Third, Education aids the ability to adapt to 
emerging business opportunities. Fourth, educational institutions are the platform for transferring knowledge and skills to future generations. Di Matteo (2003) investigated the relation between nation's income and human capital spending, results posited a strong bonding between variables of interest. While Chou (2007) corroborated strong long run relation between per capita income and $\mathrm{HC}$ in China's economy. Especially to Pakistan economy, Haider and Butt (2007) found a significant and durable relation between HC and GDP. Trade openness, pedagogical skills, inequality of income etc. exerted probative advantageous result on growing economic system in Pakistan (Asghar et. al, 2012). While Akram, et. al. (2008) probed short sighted and protracted relation between HC \& growth of the economy. The literature on human capital and economic performance confirmed that for long run growth, HC plays a significant role.

Provincial study was also carried out for Pakistan to extract the relationship between economic growth and human resource development, it was corroborated that there was no significant link in long run between stated variables for KPK and Baluchistan province, but for whole Pakistan there exists a cointegration between human resource development (HRD) and economic growth (Shahbaz, et.al, 2011). Their results further concluded that there is one way causality running from HRD to economic growth for Pakistan. Khan (2005) earlier explored that there are different determinants of growth for the economy which aids the development process but pivotal roles are played by education and health care. He corroborated that in South Asia all economies are not on the same level but few are more developed than the others one, in long run, those economies will survive and grow which would have better human capital. Sri Lanka is considered the most developed nation in terms of education, Abbas and Nasir (2001) compared the Pakistan and Sri Lanka on their HC and economic growth (EG), they found positive linkage between said variables in long run but negative in short term. Negative results were explained with respect to population growth increase in developing economies which demands to focus on primary education more than university education.

The linkage between education expenditure and economic growth in six Gulf countries was explored by Al-Yousif (2008) and documented education as pivotal to 
human capital and considered education as an input just same as factors of production, for human capital. A plethora of studies explored that education is a pivotal part for the economic performance of nation, Qadri, and Waheed (2011) by studying Pakistan economy for past thirty years concluded that human capital is positively linked with EC, and the crucial building block of human capital is education, to which government must pay a heed. Industrial growth is also linked with the skills and technologies or simply the intellectual capabilities available to it. Amjad (2005) studied the role of human capital and growth in the cotton industry of Pakistan and documented that human, physical and structural capital needs intense care for the growth of an industry which will lead towards economic growth.

If human capital lacks then the output will reduce which will reduce the overall growth of the economy (Ali, et al. 2011). According to Mehrara and Musai (2013), education produces the multiplier effect in the growth and there is strong positive long term linkage between education and economic growth. Tchalim (2015) explored the role of education levels on economic growth and revealed that primary education is the main and foremost factor that positively and significantly impacts the growth perspective of the economy. The major building block of educated society is its quality primary or basic education.

Based on the studies on human capital and economic performance, it can be hypothesized that human capital significantly and positively cointegrated with the economic performance of the nation.

\section{RESEARCH METHODOLOGY}

This segment will deal with the data and methodology used to determine the link between human capital and economic performance of South Asian economies. In order to analyze the relationship, secondary data from 1970 to 2015 is employed and panel autoregressive distributive lag (ARDL) technique is used to empirically investigate the long run relationship between the variables of interest. As Toda and Yamamoto (1995) asserted that if variables under consideration are integrated at $\mathrm{I}(0)$ and $\mathrm{I}(1)$ but none is integrated at $\mathrm{I}(2)$ then auto-regressive distributive lag methodology will provide a robust result. Causality test will be used to check either HC cause growth in the economy or vice 
versa. Data of variables is extracted from three major sources i.e. World Bank databank, Pakistan economic survey and Federal Reserve Bank of St. Louis (FRED).

\section{Variables Description}

Economic Performance (EP): Real Gross Domestic Product (GDP) per capita measures the total output of a country that is GDP divided by the number of people in the country. GDP per capita is the true measure of cross country analysis, as it helps to gauge the relative performance of economies. The rise in GDP per capita indicates economic growth which depicted in increase productivity and economic performance. As the analysis is based on longitudinal data, therefore to capture the economic performance of the South Asian economies real GDP per capita of each country is taken as a proxy. This variable is adopted from Chou (2007) and Afzal (2010).

Human Capital: Index of human capital per person, based on years of schooling (Barro and Lee, 2013) and returns to education (Psacharopoulos, 1994) is used as a proxy to capture Human Capital of an economy. Data has been extracted from FRED, Federal Reserve Bank of St. Louis on yearly basis from 1970 to 2015. Caselli (2005), Cohen, et. al (2007) and Cohen, et. al (2014) used this proxy of human capital to ascertain cross country analysis.

Physical Capital: To capture PC of the economy, a proxy of gross fixed capital formation is used. Abbas and Foreman (2008) and Iqbal (2009) used this proxy for gauging the physical capital economy.

\section{Econometric Model:}

Following model will be used to check the long term relation between human, physical capital, and performance of the economy.

$$
\begin{gathered}
E P i, t=\sum_{i=0}^{n} \beta 1 \Delta \ln (E P) i, t-1+\sum_{i=0}^{n} \beta 2 \Delta(H C) i, t-1+ \\
\sum_{i=0}^{n} \beta 1 \Delta(P C) i, t-1+\gamma 1 \ln (E P) i, t-1+\gamma 2(H C) i, t-1+\gamma 3(P C) i, t-1+\varepsilon i, t
\end{gathered}
$$

\section{RESULTS AND DISCUSSION}

To ascertain the level of integration for all variables, unit root test was applied first. As described, level of integration will preclude the usage of ARDL model. Secondly, recent literature emphasized the nature of panel data dependence; if cross section dependence is 
present in data then usage of the econometric model will be slightly modified to incorporate the data nature in it. Table 1 report the descriptive stats of the data.

\begin{tabular}{|l|c|c|c|}
\hline \multicolumn{4}{|l|}{ Table.1 Descriptive Statistics } \\
\hline & PC & HC & EP \\
\hline Mean & 6.51 & 1.71 & 3.36 \\
\hline Median & 6.79 & 1.75 & 3.38 \\
\hline Std. Dev. & 7.84 & 0.17 & 0.21 \\
\hline
\end{tabular}

\section{Cross Dependency and Panel Unit root test:}

Prior to examining the long run relation between the variables of interest in South Asian economies, checking of stationarity of the variables is essential for further progress. If variables have the problem of a unit root, then results from ordinary least square would be spurious and harmful for policy formulation. On the other side, it is commonly presumed that disturbances in panel models are not cross-sectional dependent when cross section dimension is usually large. But to check the residuals cross section dependence, before applying unit root test, will magnify the results and analysis for precise policy making. Ignoring cross-section dependence and directly applying unit root test results in estimator efficiency loss and invalid test statistics. The literature on panel unit root and cointegration testing corroborates that panel-based testing performs better than tests on individual time series because of additional information that comes from the cross-section. Literature provides two series of unit root tests i.e. first and second generation tests. First generation tests assumed that there is cross-section independence in the panel which includes Levin, Lin and Chu (LLC) (2002) test, Breitung (2000) test, Im, Pesaran, and Shin (2003) test, ADF-Fisher test and Philips Peron- Fisher test. LLC and Breitung tests assume a common unit root across the relevant cross-sections while individual unit root processes are allowed by other tests. While second generation tests are based on the assumption that cross-section independence hypothesis is rejected and residuals are not cross sectional independent. In the language of economics, it means that in a situation that units forming panel is affected by shock, then the other units of the panel are also affected as well. First generation tests will be biased if they are applied to panels with cross-section dependence (Breitung and Pesaran, 2005). For cross section dependence panels, second generation tests of panel unit 
root must be applied to check the level of integration for analyzing long term relationship which includes Cross-section adjusted Dicky Fuller (CADF) test or SURADF test developed by Breuer et.al (2001).

Before examining the level of integration of variables using panel unit root, Pesaran (2004) cross section dependence will be applied to check the cross-section dependence of residuals. $\mathrm{T}$ - stat and probability of test would help to accept or reject the null hypothesis of Pesaran test i.e. there is no cross-section dependence across panels. Im et.al (2003) IPS panel unit root test will be applied because for balanced panel the most suitable test that deals in cross-sectional units heterogeneity, is IPS (Khan et.al, 2005), which is based on following autoregressive model,

$$
\mathrm{Yi}, \mathrm{t}=\rho i Y i, t-1+\sum \theta \mathrm{i}, \mathrm{j} \Delta \mathrm{Yi}, \mathrm{t}-1+Z i, t+\varepsilon i, t
$$

having non-stationarity $\rho \mathrm{i}=1$ for all i., null hypothesis.

This study explored the long run relation between human capital and economic performance of South Asian countries. Panel unit root test applied to check the stationarity of the variables. Before examining the level of integration of variables using panel unit root, Pesaran (2004) cross section dependence test has been applied to check the crosssection dependence of residuals. T-stat and probability of test show insignificant values which accept the null hypothesis of Pesaran test i.e. there is no cross-section dependence across panels. Results are depicted in Table 2.

\begin{tabular}{|l|c|c|}
\hline \multicolumn{3}{|c|}{ Table.2: Residual error cross section dependence test } \\
\hline & Stat & Prob \\
\hline Pesaran CD & 0.755 & 0.4499 \\
\hline
\end{tabular}

This test further leads to a conclusion that first-generation panel unit root test can be applied to check the level of integration of variables. To deal with heterogeneity issues across a cross section of a balanced panel Im et.al (2003) IPS panel unit root test is suitable. Results of panel unit root test are given in Table 3.

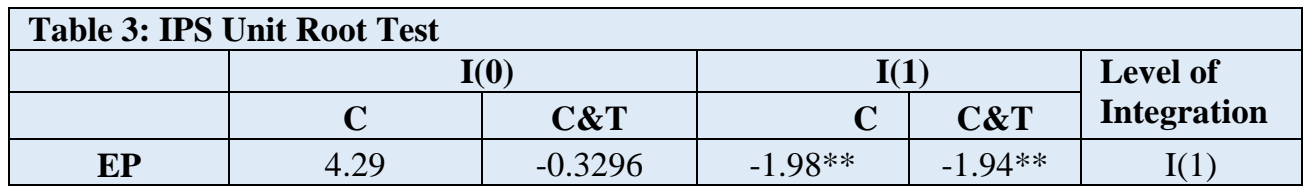




\begin{tabular}{|c|c|c|c|c|c|}
\hline HC & 3.04 & -0.885 & $-1.65 * *$ & $-1.67 * *$ & $\mathrm{I}(1)$ \\
\hline PC & $-6.75 * *$ & $-6.62 * *$ & $-13.56 *$ & $-13.18 *$ & $\mathrm{I}(0)$ \\
\hline \multicolumn{6}{|c|}{$* 99 \%, * * 95 \%, * * * 90 \%$ level of significance } \\
\hline \multicolumn{6}{|c|}{$\mathrm{C}=$ constant, $\mathrm{C} \& \mathrm{~T}=$ constant + trend } \\
\hline
\end{tabular}

Results depict that physical capital has no unit root at the level and therefore it is integrated at I (0). While EP and $\mathrm{HC}$ both have unit root at level but not at first difference, therefore, both variables are integrated at first difference I(1). If all variables are integrated of the same order at degree one, then employing error correction model will give robust results. ARDL approach will be the ideal technique to identify the existence of long run and short run relationships if the level of integration is different across variables but no series have shown above I (1) integration. There are two stages of ARDL, first, F-statistics is used to determine the significance of the lagged level variables for a long run relationship. Secondly, long run and short run intensity will be examined. Before reporting ARDL and bound test, the optimal level of lag required to be known for a robust result. Table 4 provides lag selection criteria.

\begin{tabular}{|l|c|c|c|c|}
\hline \multicolumn{6}{|l|}{ Table 4: Lag Selection } \\
\hline ARDL(p,qk) & LogL & AIC & BIC* & HQ \\
\hline ARDL(1,1,1) & 244.72 & -7.08 & -6.52 & -6.91 \\
\hline ARDL(1,2,2) & 250.31 & -7.07 & -6.50 & -6.85 \\
\hline ARDL(1,3,3) & 259.70 & -7.17 & -6.41 & -6.87 \\
\hline ARDL(2,1,1) & 250.11 & -7.16 & -6.69 & -6.97 \\
\hline ARDL(2,3,3) & 264.79 & -7.24 & -6.37 & -6.90 \\
\hline ARDL(2,4,4) & 268.81 & -7.08 & -6.02 & -6.67 \\
\hline * Criteria used for lag selection
\end{tabular}

Table 3 shows the leg length selection for ARDL(p,q) process. Schwartz Bayesian Information Criterion (BIC) is used to know the lag length. According to BIC ARDL $(2,1,1)$ model is preferred because of lowest BIC value. Table further reports Akaike Information criterion (AIC), Hannan Quinn (HQ) and Loglikelihood (LogL) test statistics. According to BIC and HQ, ARDL $(2,1,1)$ process is efficient for the long run analysis of Human capital and economic performance.

As there are two stages of ARDL, the first stage is using F-statistics for testing of the long run relationship between variables. The bound test is used which investigates the 
long run relationship between dependent and independent variables. As p-value of F-stat and Chi-square is significant, therefore null hypothesis of test can be rejected and presence of long run relationship amongst variables of interest can be concluded. It is concluded that human capital \& physical capital are co-integrated with the performance of an economy. Table 45enlist the details of the test.

\begin{tabular}{|l|c|c|}
\hline Table 5: Wald Test & Probability \\
\hline Test Statistic & Value & $0.0000^{*}$ \\
\hline F-statistic & 76.28 & $0.0000^{*}$ \\
\hline Chi-square & 152.57 & \\
\hline$*=99 \%, * *=95 \%$ and $* * *=90 \%$ level of significance & \\
\hline
\end{tabular}

Next stage of ARDL approach to co integration is to determine the coefficient of $\log$ run and short run relationship. Results of long term showed that human capital and physical capital both positively influence the performance of the economy. Further, it can be corroborated that one percent increase in human and physical capital of an economy will enhance performance by $2.5 \%$ and $0.4 \%$. In long run, human capital development aids the economy by providing knowledge management inventory which facilitates the sustainable development. As human capital increases, the level of education, enrollment, and returns to education increase which facilitates the economy in terms of production, innovation, and technology which all leads to the growth of an economy. The coefficient of COINTEQ depicts the error correction term which is significant and negative according to theory. Further short term analysis of South Asian economies revealed that in short run human capital and physical capital do not significantly impact the economy but their relationship is still positive. As the development of human capital is long term process, one time investment on it will provide benefit in the long run. As in a company, one time investment on asset reduces the cash flows in short run but in long run, that same asset helps in the development of profitability cliff.

\begin{tabular}{|c|c|c|c|c|}
\hline Table 6 (a): ARDL results \\
\hline Variable & Coefficient & Std.error & T-stat & Prob \\
\hline Long run & \multicolumn{5}{|l|}{} \\
\hline HC & 2.530 & 0.239 & 10.603 & $0.0000 *$ \\
\hline
\end{tabular}




\begin{tabular}{|c|c|c|c|c|}
\hline PC & 0.045 & 0.021 & 2.180 & $0.0334 * *$ \\
\hline Short Run & \multicolumn{5}{|l|}{} \\
\hline D(LNEP(-1)) & 0.32 & 0.16 & 1.96 & 0.0550 \\
\hline D(PC) & 0.00 & 0.00 & 1.75 & $0.0917 * * *$ \\
\hline D(HCI) & 0.14 & 0.08 & 1.78 & $0.0896 * * *$ \\
\hline COINTEQ & -0.01 & 0.00 & -8.42 & $0.0000 *$ \\
\hline$*=99 \%, * *=95 \%$ and $* * *=90 \%$ level of significance \\
\hline
\end{tabular}

Table 6(b) further explored the short run cross section results. In all countries of South Asia under study, the relationship between physical \& human capital with the performance of the economy is mixed. As it can be argued that in short run economies consider investment on human and physical capital as a burden on the economy because of no apparent and quick benefits from this investment. HC investment develops the capital in long run whose benefits are gradually inculcated in the economic mainstream.

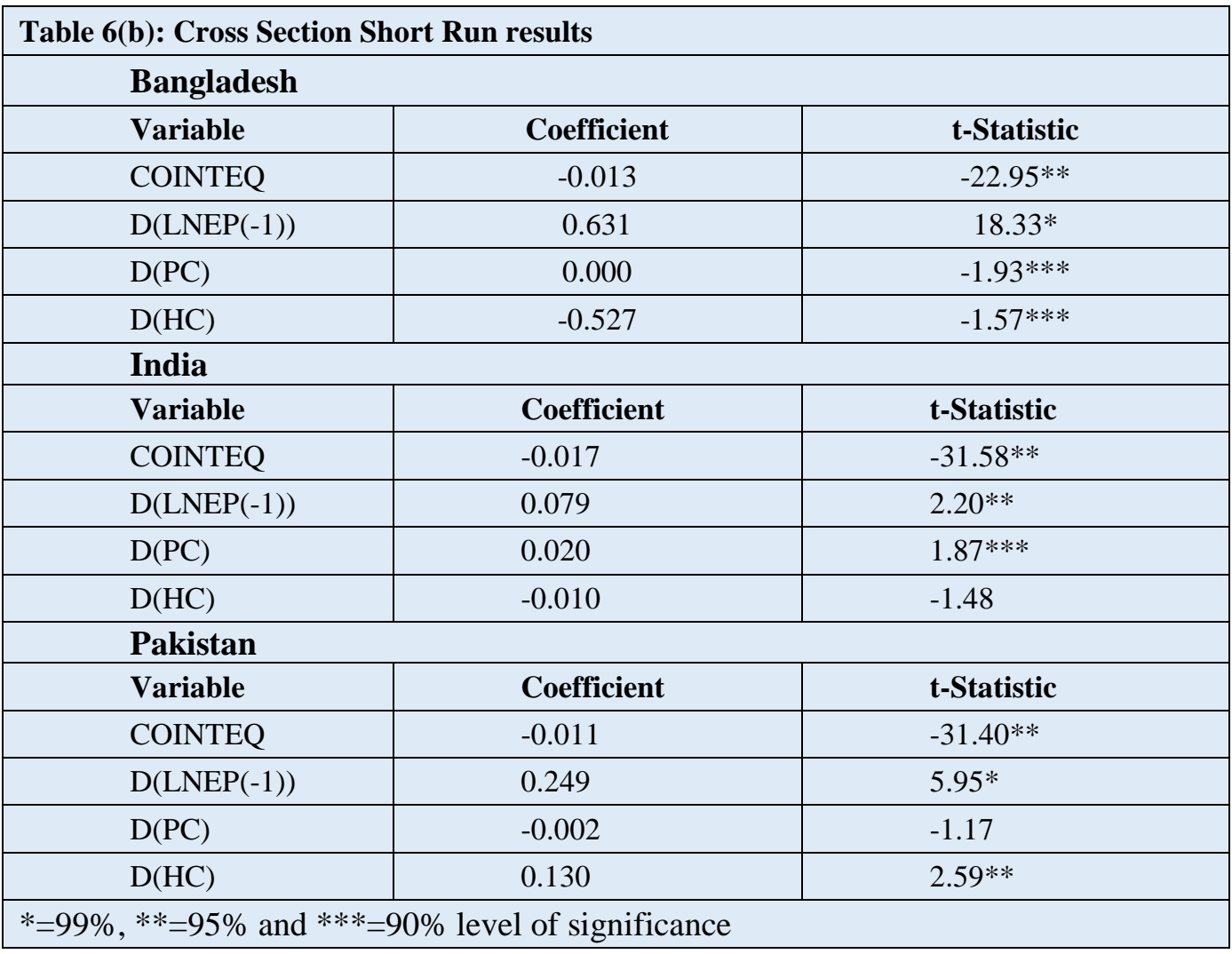


After developing long term relationship between $\mathrm{HC}$ and EC, pairwise Dumitrescu and Hurlin (2012) panel causality test was used to determine causality amongst the series. Human capital and EP both bi-directional cause each other. In long run returns to education and more investment in education aids the economic performance of the economy. In turn, policymakers allocate a significant portion of their GDP to education so that virtuous cycle of prosperity continues. While uni-directional causality is established amongst physical capital and economic performance, the better perform an economy will be, the more it will build physical capital. Physical capital also induces the human capital according to empirical result. This all corroborates that human capital is the most important and critical factor that influences and aids in economic performance while physical capital solely cannot determine and facilitates the economic performance.

\begin{tabular}{|l|c|c|c|}
\hline \multicolumn{4}{|l|}{ Table 7: Pairwise Dumitrescu Hurlin Panel Causality Tests } \\
\hline \multicolumn{1}{|c|}{ Null Hypothesis: } & W-Stat. & Zbar-Stat. & Prob. \\
\hline PC does not homogeneously cause EP & 1.50627 & -0.50812 & 0.6114 \\
\hline EP does not homogeneously cause PC & 7.67796 & 3.61594 & $0.0003^{*}$ \\
\hline HC does not homogeneously cause EP & 7.56672 & 3.54161 & $0.0004^{*}$ \\
\hline EP does not homogeneously cause HC & 6.31823 & 2.70734 & $0.0068^{*}$ \\
\hline HC does not homogeneously cause PC & 3.35698 & 0.96687 & 0.3336 \\
\hline PC does not homogeneously cause HC & 11.9245 & 7.61585 & $0.0000^{*}$ \\
\hline
\end{tabular}

\section{CONCLUSION}

The main aim of this study was to explore the nexus between a most important component of intellectual capital i.e. Human Capital and Economic Performance for South Asian countries over the period 1970-2015. After checking for cross section dependency, panel unit root test was applied to explore the level of integration. As variables of interest are integrated at $I(0)$ and $I(1)$ and not a single variable is integrated at $I(2)$, therefore Panel ARDL and Dumeitrescu and Hurlin (2012) non-homogeneous panel causality test was applied. It was concluded that there is a positive and significant link between human capital and economic performance of the economy. In short run, there is an insignificant link established in Indian and Bangladesh economy which posits that in short run investment in human capital is not prevalent. In short run Pakistani economy posits a positive link 
between human capital and economic growth i.e. more investment on education in an economy will lead to better performance of the economy. But long term effect is preeminent for all South Asian economies. Causality test further explored that there is bidirectional causality amongst the variables of interest.

\section{Policy Implication:}

This study implies that any shock to the performance of the economy will also affect the human capital of an economy and vice versa. Policymakers of South Asian economies require focussing on human capital development because of emerging states of economies where growth in the economy can be enhanced through human development along with other factors. To achieve a high level of human capital, more investment in the development of human resource for an economy is an essential factor for growth and sustainable development. United Nations Millennium Development Goal (MDG-2) also posits that developing nations must achieve a milestone in education through heavy investment on the education sector and necessary primary education for all. While the majority of South Asian and other underdeveloped nation failed to achieve this goal of United nation till 2015 because the focus of these economies always remains to build physical capital. In 2016 UN presented Sustainable development Goal plan, and according to SDG-4 quality education is the most important factor of economic sustainable growth and development. To aspire good economic sustainable growth, economies have to spend more on education so that every citizen has easy and almost free access to basic education which will ultimately build the human development of an economy that can aid in sustainable economic growth. The focus must be on balance between development of intellectual capital i.e. human capital and physical capital for sustainable growth in economies.

This study explored the link between HC and performance of South Asian economies for a period of three decades almost. Future studies can be conducted by utilizing pre and post-industrialization effect of $\mathrm{HC}$ on performance. As after industrialization, the focus on human development increased with a surge in 
mechanization. Therefore, further, it can be ascertained that how South Asian economies as the whole affected economic growth of nations in pre and post-industrialization periods.

\section{REFERENCES}

Abbas, Q., \& Foreman-Peck, J. S. (2008). Human capital and economic growth. Lahore Journal of Economics, 13(1), 1-27.

Abbas, Q., \& Nasir, Z. M. (2001). Endogenous growth and human capital: A comparative study of Pakistan and Sri Lanka. The Pakistan Development Review, 39(4), 451-473.

Afzal, M. (2010). The relationship between school education and economic growth in Pakistan: ARDL bounds testing approach to cointegration. Pakistan Economic and Social Review, 48(1), 39-60.

Akram, N. (2008). The long term Impact of health on economic growth in Pakistan. The Pakistan Development Review, 47(4), 487-500.

Ali, S., Farooq, F., \& Chaudhry, I. S. (2011). Human capital formation and economic growth in Pakistan. Pakistan Journal of Social Sciences, 32(1), 229-240.

Al-Yousif, Y. K. (2008). Education expenditure and economic growth: Some empirical evidence from the GCC countries. The Journal of Developing Areas, 42(1), 69-80.

Amjad, R. (2005). Skills and competitiveness: Can Pakistan break out of the low-level skills trap? The Pakistan Development Review, 44(4), 387-409.

Asghar, N., Awan, A., \& Rehman, H. U. (2012). Human capital and economic growth in Pakistan: A cointegration and causality analysis. International Journal of Economics and Finance, 4(4), 135- 147.

Barro, R. (1991) Economic Growth in a Cross Section of Countries. The Quarterly Journal of Economics, 106, 407-443.

Barro, R.J. (2001) Human Capital and Growth. American Economic Review, 91, 12-17.

Barro, R. J., and Jong W. L. (2013). "A New Data Set of Educational Attainment in the World, 1950-2010." Journal of Development Economics 104: 184-98.

Barro, Robert J., and Sala-i-Martin, Xavier (1992). Convergence across States and Regions, Brookings Papers Econ. Activity, 1, 107-82.

BBVA (2015) Research report on country analysis. Available at: https://www.bbvaresearch.com/en/publicaciones/country-risk-report-second-quarter-2015/

Breitung, J. (2000). The Local Power of Some Unit Root Tests for Panel Data, in Nonstationary Panels, Panel Cointegration, and Dynamic Panels, Advances in Econometrics, Vol. 15, ed. by B. Baltagi. JAl, Amsterdam.

Breitung, J. and M.H. Pesaran (2005): "Unit Roots and Cointegration in Panels," Deutsche Bundesbank Discussion Paper Series 1: Economic Studies.

Breuer, J. B., McNown, R., and Wallace, M. S. (2001). Misleading inferences from panel unit root tests with an illustration of purchasing power parity. Review of International Economics, 9(3): 482-493.

Chou, W. L. (2007). Explaining China's regional health expenditures using LM-type unit root tests. Journal of Health Economics, 26, 682-698.

Caselli, Francesco (2005). Accounting for cross-country income differences. Handbook of Economic Growth, Volume 1A, Elsevier: 679-741.

Cohen, Daniel and Marcelo Soto (2007). Growth and human capital: good data, good results. Journal of Economic Growth 12(1): 51-76.

Cohen, Daniel and Laura Leker (2014). Health and Education: Another Look at the Proper Data", mimeo Paris School of Economics.

Di Matteo, L. (2003). The income elasticity of health care spending. A comparison of parametric and nonparametric approaches. European Journal of Health Economics, 4(1), 20-29. 
Dumitrescu, E.-I., \& Hurlin, C. (2012). Testing for Granger non-causality in heterogeneous panels., Economic Modelling, 29(4), 1450-1460.

Edvinsson, L. (1997). Developing intellectual capital at Skandia.Long Range Planning, 30(3),366-373.

Haider, A., \& Butt, S.M. (2007). The Direction of Causality between Health Spending and GDP: The Case of Pakistan. Pakistan Economic and Social Review, 45, 125-140.

Im, K. S., Pesaran, M. H., \& Shin, Y. (2003). Testing for unit roots in heterogeneous panels. Journal of Econometrics, 115(1), 53-74.

Jorgenson, D.W., and Fraumeni, B.M. (1989) The Accumulation of Human and Non- Human Capital, 19481984. In: Lipsey, R.E., and Tice, H.S., Eds., The Measurement of Savings, Investment and Wealth, University of Chicago Press, Chicago, 227-282.

Khan, M. (2005) Human Capital and economic growth in Pakistan. The Pakistan Development Review, 44(4), 445-478.

Levin, A., C.-F. Lin and C.-S. J. Chu (2002): "Unit Root Tests in Panel Data: Asymptotic and Finite-Sample Properties," Journal of Econometrics, 108(1), 1-24.

Mehrara, M., \& Musai, M. (2013). The relationship between economic growth and human capital in developing countries. International Letters of Social and Humanistic Sciences, 5, 55-62.

Pesaran, M.H., Schuermann, T., and Weiner, S.M. (2004), Modeling Regional Interdependencies using a Global Error-Correcting Macroeconomic Modelî, Journal of Business Economics and Statistics, 22, 129-181.

Psacharopoulos, George, (1994). Returns to investment in education: A global update. World Development, Elsevier, 22(9), 1325-1343.

Qadri, F. S., \& Abdul Waheed, W. (2011). Human capital and economic growth: Time series evidence from Pakistan. Pakistan Business Review, 1, 815-833

Schultz, T.W. (1963). The economic importance of human capital in modernization. Education Economics, 1(1), 13-19

Shahbaz, M., Iqbal, A., \& Butt, M. S. (2011). Testing causality between human development and economic growth: A panel data approach. International Journal of Education Economics and Development, 2(1), 90-102.

Solow, R.M. (1956) A Contribution to the Theory of Economic Growth. Quarterly Journal of Economics, 70, 6594.

Tchalim, T. (2015) Levels of Education and Economic Growth in Togo. African Integration and Development Review, 8, 1-27.

Toda, H.Y. \& Yamamoto (1995) Statistical inference in Vector Autoregressions with possibly integrated processes. Journal of Econometrics, 66, 225-250.

UN, MDG (2015). Millenium Development Goals report. Available at :http://www.un.org/millenniumgoals/2015_MDG_Report/pdf/MDG\%202015\%20rev\%20(July \%201).pdf

UN, SDG (2016).Sustainable Development Goals report. Available at: http://unstats.un.org/sdgs/report/2016/The\%20Sustainable\%20Development\%20Goals\%20R eport\%202016.pdf

UNESCO Report (2013). Available at: http://unesdoc.unesco.org/images/0022/002271/227146e.pdf 